\title{
STUDIE
}

\section{Vznik světa podle Anaximandra ${ }^{i}$}

\section{Radim Kočandrle}

Kosmogonie představuje jeden z nejpodstatnějších momentů každého výkladu světa. Popis toho, jak svět vzniká a vytváří se do své výsledné podoby, je zároveň jedním z klíču k pochopení každé kultury. Způsob reflexe světa typický pro západní styl myšlení se zrodil na půdě archaické Iónie. Podle Aristotela začíná Thalétem z Mílétu. Můžeme se však domnívat, že až Anaximandros z Mílétu napsal spis, o němž máme doklady. Ve 4. století po Kr. konstantinopolský Themistios poznamenává:

„Anaximandros se jako první z Řeků, o kterých víme, odvážil vydat psaný výklad o př́rodě. “ii

Ze spisu se zachovala patrně pouze jedna věta, slovní spojení či pouhá slova. Nemůžeme si proto činit nárok na to, že bychom dokázali rekonstruovat jeho text. V obecném povědomí je s archaickou filosofií

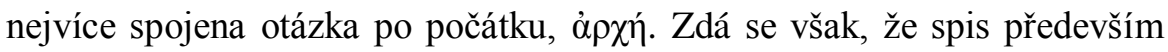
vykládal jednotlivé fenomény světa, nebot' jsou to astronomická a

\footnotetext{
${ }^{\text {i }}$ Studie je realizována na základě grantového projektu GA ČR P401/10/0520.

ii Themistios, Or. 36,317=DK 12 A 7. Není-li uvedeno jinak, překlady antických autorů pořídil na základě starších překladů $\mathrm{V}$. Hladký a kol.
} 
meteorologická témata, která v dochovaných referátech převládají. Spis pojednával nejen o podobě nebeských těles, meteorologických jevech, ale rovněž o vzniku života. A současně o vzniku celého světa. Je-li Anaximandros z Mílétu autorem prvního podobného spisu, jedná se současně o první filosofický výklad kosmogonie vůbec.

Naše rámcové povědomí o Anaximandrově kosmogonii se ve své podstatě zakládá pouze na krátkém svědectví Pseudo-Plútarchových Stromat, částečně doplněné Hippolytem ${ }^{\mathrm{i}}$ a Áetiem ${ }^{\mathrm{ii}}$. Obecně se předpokládá, že Pseudo-Plútarchos zprostředkovává Theofrastův text

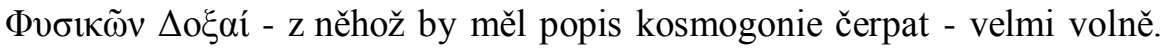
Uvedeme postupně celý Pseudo-Plútarchův referát, který edice DielsKranz označila $D K 12$ A $10{ }^{\text {iii }}$ Zachovává jej Eusebios v Praeparatio evangelica, ${ }^{\text {iv }}$ přičemž celý text uvozuje větou, jíž $D K$ vypouští:

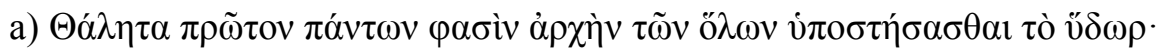

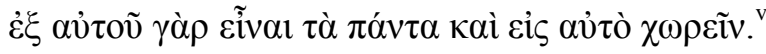

„Thalés byl prý první, kdo předpokládal, že počátkem veškerenstva je voda, nebot' z ní všechno je a do ní se navrací.“

Pokračují slova referátu, jehož první část má v našem dělení znění:

\footnotetext{
${ }^{\mathrm{i}}$ Hippolytos, Ref. I,6,4 = DK 12 A 11.

ii Áetios, Plac. II,11,5 = DK 12 A 17a.

iii Pseudo-Plútarchos, Strom. $2=D K 12$ A 10.

${ }^{\text {iv }}$ Eusebios, Praep. evan. I,8,2.

${ }^{v}$ Eusebios, Praep. evan. I, 8,1 .
} 


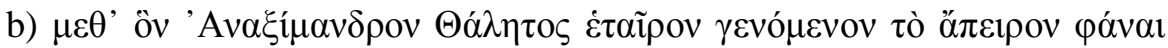

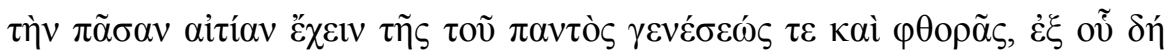

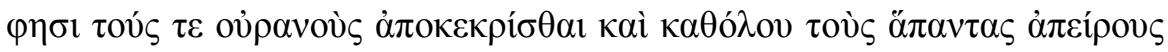

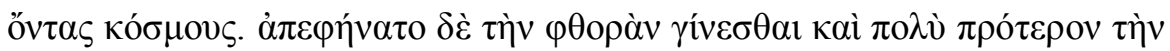

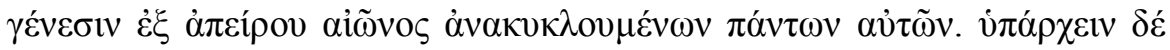

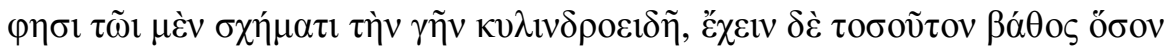

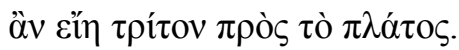

„Po Thalétovi tvrdil jeho druh Anaximandros, že bezmezné je prŕíčinou vznikání a zanikání veškerenstva. Praví, že z něj se odloučila nebesa a vůbec veškerá světová uspořádání, jež jsou bezmezná. Dále řekl, že zánik a tím spíše vznik se děje z bezmezného aiónu (života, věku?), protože se všechna tato [uspořádání] navracejí. Řekl také, že Země je podoby válcové, a že její hloubka je třetinou její šiřrky.“

Inkriminovaná pasáž následuje bezprostředně po informaci o válcové podobě Země a její třetinové hloubce oproti šířce. Může se jednat o vsuvku opisovače, nebot' podobnou konkrétní zprávu bychom spíše očekávali až po popisu kosmogonie. Jednotlivé věty referátu jsou však téměř vždy uvozeny slovy ,„ríká dále“ naznačujících útržkovitost témat.

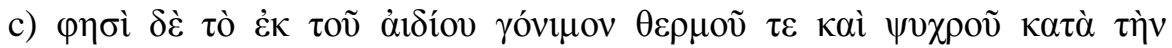

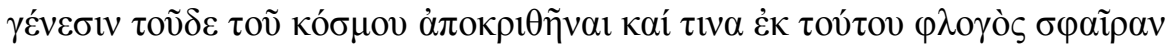

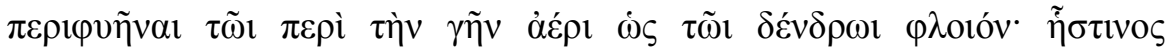
ả

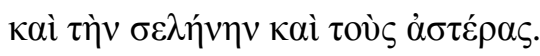


Terminologicky je obtížně vyložitelný již začátek celé pasáže. Nabízíme proto dva překlady:

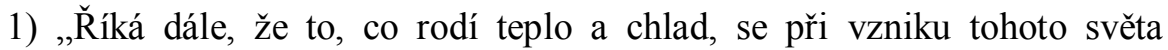
odloučilo z toho, co trvá, a z něj vyrostla kolem vzduchu, který je okolo Země, jakási planoucí sféra jako kůra kolem stromu. Když se tato sféra rozlámala a uzavřela do jakýchsi kruhů, ustavilo se Slunce, Měsíc a hvězdy."

2) „Ř́íká pak, že to, co plodí, se při vzniku tohoto světa odloučilo z věčného tepla a chladu a $\mathrm{z}$ něj vyrostla kolem vzduchu, který je okolo Země, jakási planoucí sféra, jako kůra kolem stromu. Když se tato sféra rozlámala a uzavřela do jakýchsi kruhů, ustavilo se Slunce, Měsíc a hvězdy.“

Pseudo-Plútarchovu zprávu uzavírají informace o vzniku člověka:

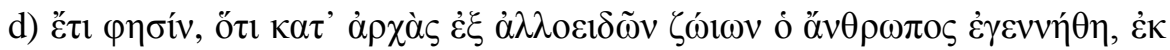

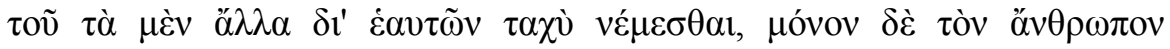

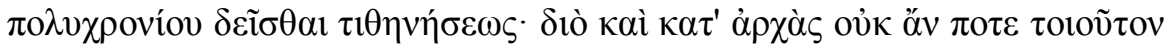
öv $\alpha \alpha \delta 1 \alpha \sigma \omega \theta \tilde{\eta} v \alpha 1$.

„Kromě toho říká, že člověk se původně zrodil z živočichů jiného druhu, protože ostatní živočichové se brzy sami živí, pouze člověk potřebuje být 


\section{AIOHIP II. 3}

velmi dlouho kojen. Proto by se neudržel při životě, kdyby takový byl už od počátku.“

U Eusebia celý text navíc končí větou, kterou $D K$ opět vypouští:

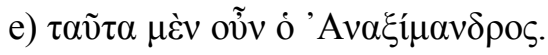

„Toto jsou názory Anaximandrovy.“

V naší studii se budeme věnovat pouze kosmogonické pasáži c). Její výklad však působí značné problémy, nebot' již význam první věty je temný a překlad problematický. H. Diels v Doxographi Graeci pokládal

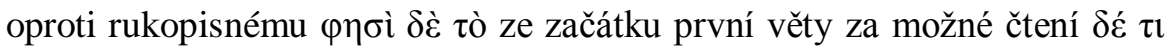

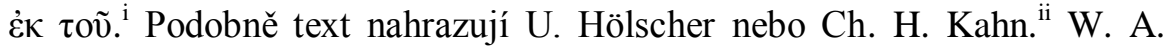

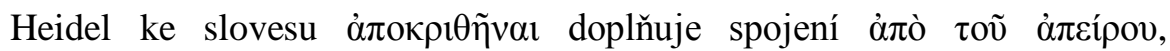

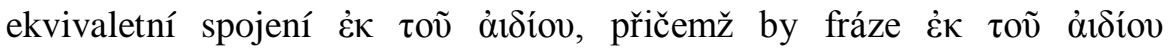

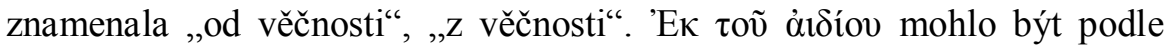

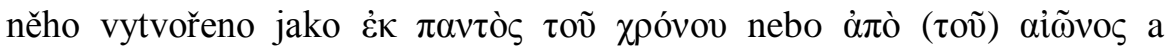

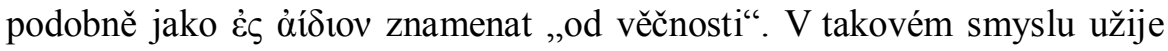

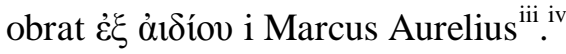

\footnotetext{
${ }^{\mathrm{i}}$ Srv. Dox. 1879, s. 579.

${ }^{i i}$ Srv. Hölscher 1970, s. 290-292; Kahn 1960, s. 57.

iii Marcus Aurelius, Ad se ips. II,14; IV,21; 10,5.

${ }^{\text {iv }}$ Srv. Burnet 1930, s. 63; Heidel 1912, s. 229; 1913, s. 687.
} 
Začátek textu bychom asi měli pochopit $\mathrm{v}$ tom smyslu, že se na počátku celého světa z toho, co trvá, oddělilo něco, co bylo dále schopné rodit teplo a chlad. Podobnému čtení je poplatný i první z našich překladů. Vložení

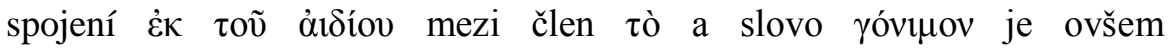
problematické. G. S. Kirk rozlišuje dvě varianty: „Tvrdí, že to, co $\mathrm{z}$ věčného plodí teplo a chlad, se oddělilo při vzniku tohoto světa...“ a „to, co bylo po celý čas schopno plodit..." (přel. F. Karfík), kde by pak ale spíše

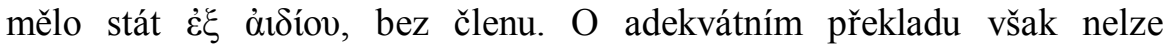
dostatečně rozhodnout již vzhledem k tomu, že chybí členy u tepla a

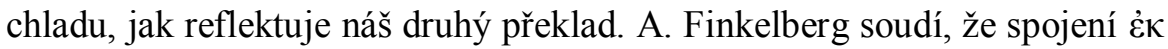

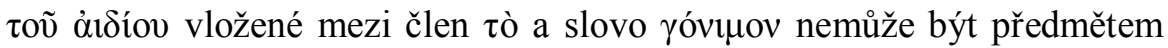

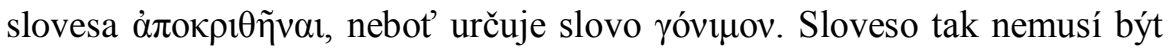
užito ve spojení s předmětem a má zde spíše význam ,vytvořilo se“, „odlišilo se“. Гóvuov by se tak z věčného neoddělilo, ale vytvořilo by se v něm. V každém př́ipadě tím, co se oddělilo či odlišilo, bylo yóvıนov, již vzhledem k předložce è , která má vnitřní význam. ${ }^{i}$

\section{Co trvá}

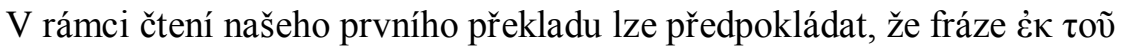

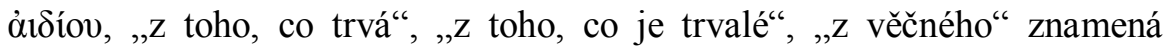

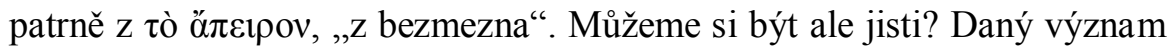

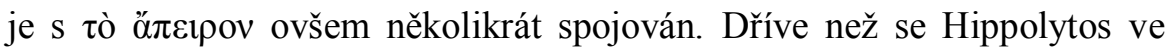

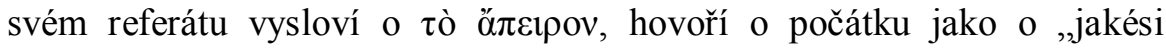
přirozenosti bezmezna“", která je „trvalá a nestárnoucí“":

${ }^{\mathrm{i}}$ Srv. Finkelberg 1993, s. 245-246; Hölscher 1970, s. 290-292; KRS 2004, s. 169. 
„Za počátek jsoucích věcí prohlásil [Anaximandros] jakousi přirozenost

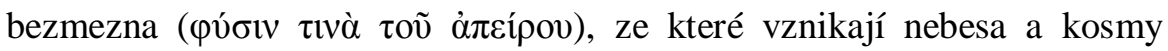

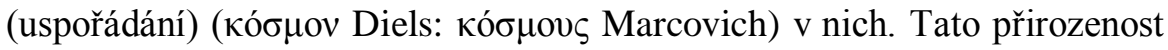

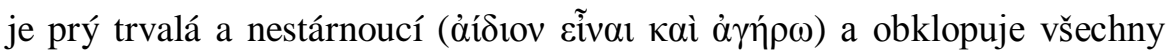

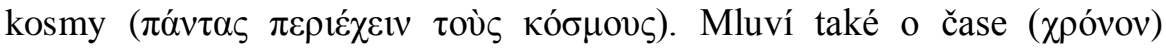
jakožto o vymezeném vzniku jsoucích věcí, tak jejich zániku. “i

Sám Aristotelés na jediném místě, kde jmenovitě spojí Anaximandra s

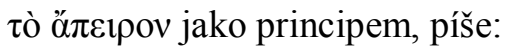

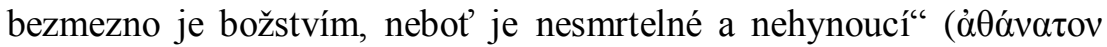
$\gamma \grave{\alpha} \rho \kappa \alpha i ̀ ~ \alpha ́ v \omega ́ \lambda \varepsilon \theta \rho o v) .{ }^{i i}$

Možná jen tato slova se z celé pasáže Fyziky skutečně vztahují k Anaximandrovi. Aristotelés ještě předtím prohlásí, že bezmezno je

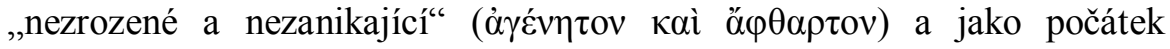

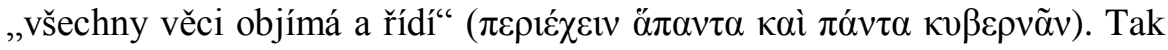
se měli vyjadřovat ti, kdo podle Aristotela mimo bezmezno nepředpokládali jiné př́ičiny. ${ }^{\text {iii }}$

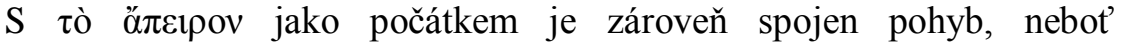
Anaximandrův princip měl být pohyblivý a zároveň jeden a bezmezný, jak dosvědčuje Simplikios v úvodu svého referátu. ${ }^{\text {iv }}$ Podobně podle Hippolyta:

${ }^{\mathrm{i}}$ Hippolytos, Ref. I,6,1 = DK 12 A $11=D K 12$ B 2.

ii Aristotelés, Phys. 203b13-14=DK 12 A $15=D K 12$ B 3.

iii Aristotelés, Phys. 203b8-13 = DK 12 A 15.

${ }^{\text {iv }}$ Simplikios, In Arist. Phys. 24,13 = DK 12 A 9. 


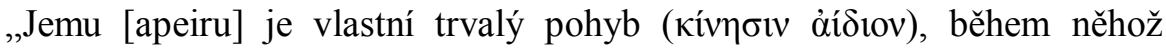
dochází k tomu, že vznikají nebesa. “i

Věčnost nebo trvalost je tak spojována i s pohybem. Je to věčný pohyb, kterým se měly oddělovat protiklady a tím docházet ke vzniku, jak se tentokrát v dovětku svého referátu vyjadřuje Simplikios:

„Podle něj vznik není působen proměnou prvku, ale oddělováním

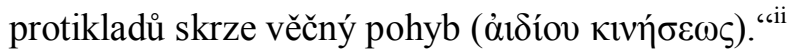

Pohyb je přirozeně zároveň v úzkém vztahu ke vzniku a zániku, jak referuje Hermiás:

„Jeho [Thalétův] spoluobčan Anaximandros ř́ká, že věčný pohyb je nejstarším počátkem vlhkého a že věčným pohybem se jedny věci rodí a jiné zanikají.،iii

nebo jinde v kontextu nekonečných světů i Simplikios:

„Nebot' ti, kdo předpokládali, že světy jsou co do svého množství nekonečné, jako následovníci Anaximandra, Leukippa, Démokrita a

\footnotetext{
${ }^{\mathrm{i}}$ Hippolytos, Ref. I,6,2 = DK 12 A 11.

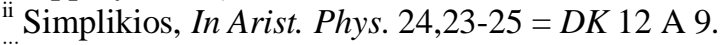

iii Hermiás, Irr. gent. phil. $10=D K 12$ A 12 .
} 
později Epikúra, předpokládali také to, že vznikají a zanikají do nekonečna. Ř́kali, že zatímco vždy jedny vznikají, jiné zanikají, a že je věčný pohyb, nebot' bez pohybu není vznik nebo zánik. “ii

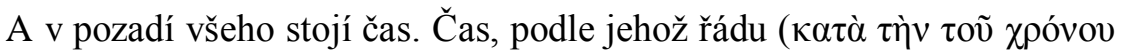
$\tau \alpha{ }^{\prime} \xi$ iv) si vše jsoucí navzájem platí trest a pokutu v prvním filosofickém textu, Anaximandrově zlomku $D K 12$ B 1. Řád času odměřuje nutnost vzniků a zániků všeho. Je garantem každé splátky. V jeho rámci má vše své vyhrazené místo. Rád času určuje trvalost pohybu, který až na jeho pozadí může být věčný.

Možná se právě tento význam vrací v Pseudo-Plútarchově zprávě, kdy

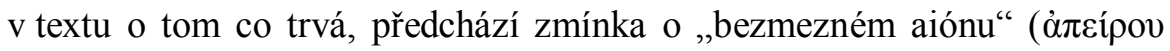
aĩ̄vos), z něhož se děje vznik a zánik, nebot' se všechna uspořádání navracejí. Vždyt' každá věc vzniká v čase a jako pomíjející je vždy pouze dočasná. Všeho do času. Co je ale aióv? V archaické době nejspíše nese především význam ,život“. Později znamená rovněž ,věk“ nebo dokonce „věčnost". ii Patrně právě důraz na aspekt věku (časové vymezení) je pro pozdního zachovávajícího autora nosný.

Nejedná-li se o akcent na předtím uvedený „bezmezný aión“, užití

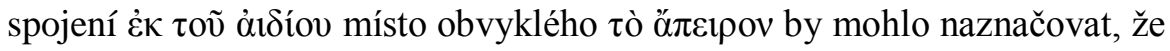
text je dokonce parafrází původních slov. Zvláště když se v něm následně objevuje slovo $\varphi \lambda$ oióc, užité u Áetia v případě kưry obklopující první živé bytosti.

Na základě výše uvedeného lze předpokládat, že v rámci prvního překladu to, co trvá, by mělo být skutečně $\tau$ ò ő $\pi \varepsilon 1 \rho o v$, které sklenuje uváděné významy. Současně právě z něho mají vznikat všechna nebesa a kosmy (uspořádání).

\footnotetext{
${ }^{\mathrm{i}}$ Simplikios, In Arit. Phys. 1121,5 = DK 12 A 17.

${ }^{i i}$ Srv. $L S J$, s.v. $\alpha i \omega ́ v$.
} 
Naprosto jiné čtení však získáme u druhého z předložených překladů. Věčné by tak byly protiklady tepla a chladu. Až z nich se následně odloučilo to, co plodí. V takovém prŕípadě jakoby text pojednával až o další

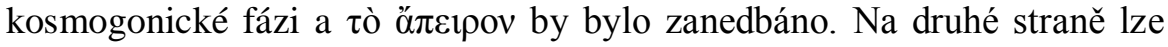

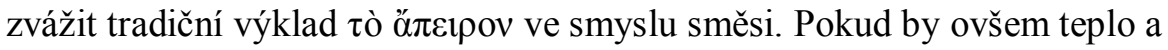
chlad byly skutečně tím, co je věčné, mohl by získat podporu předpoklad,

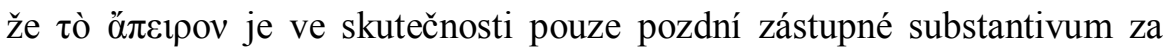
původní adjektivum. Ačkoli nemáme přímé důkazy, Anaximandros mohl

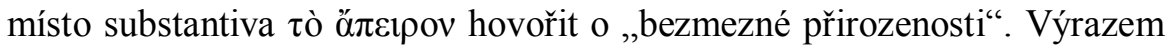
této bezmezné přirozenosti by byla diference právě na pozadí protikladů tepla a chladu a zároveň všech ostatních protikladů. Zatímco každé vznikání a zanikání je bezmezné, to, co vzniká, je určené diferencemi a vymezené časem. Tò ở $\varepsilon 1 \rho o v$ by nebylo nějaké ,něco“, ale vůbec výraz pro základ možnosti a vnitřní spojitost každé diference. Není pasáž pouze důrazem na vzájemné provázání protikladů? ${ }^{i}$

\section{Co rodí - plodí}

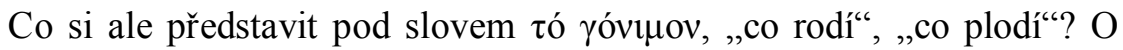
jeho pravosti u Anaximandra lze pochybovat vzhledem ke sporadickému výskytu před Aristotelem. V 5. století je doložené vlastně jen u Euripida v Elektřre a Aristofana v komedii Žáby, kde označuje ,plodivého básníka“. iii Jako termín pro kritické období nemoci je užit rovněž u Hippokrata. Jakékoli další významy tak mohou být spíše poplatné až pozděším pohledům a v souvislosti $\mathrm{s}$ Anaximandrem jsou tudíž bezpředmětné. $H$. Diels se v $D K$ přesto domníval, že výraz může pocházet

\footnotetext{
${ }^{\text {i }}$ Srv. Kratochvíl 2010, kap. 9, v tisku.

ii Euripidés, El. 118.

iii Aristofanés, Ran. 96, 98.
} 
dokonce přímo od Anaximandra. Minimálně jej pokládal za Theofrastův s odvoláním na Porfyria (De abst. II,5). U. Hölscher ${ }^{\mathrm{i}}$ odkazuje na vhodnější

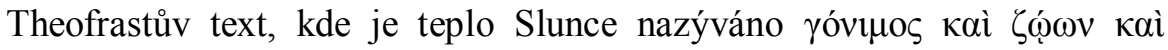

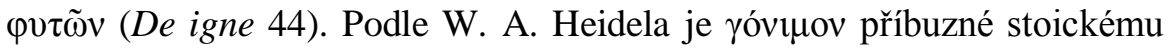

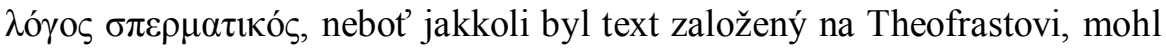

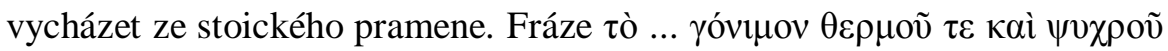

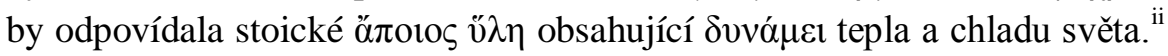
Je možné, že význam slova yóvıuov je zachován u Eirénaia jako seminaliter habens ... genesin. ${ }^{\text {iii }}$ Výraz tak mohl být opravdu Theofrastův, nicméně jeho užití Anaximandrem je sporné. Jak upozorňuje Ch. H. Kahn, autoři 5. století se v podobných prŕípadech obvykle vyjadřovali $\mathrm{v}$ daleko konkrétnějších termínech, přičemž jako příklad lze uvést $\sigma \pi \varepsilon ́ \rho \mu \alpha \mathrm{u}$ Anaxagory $^{\text {iv }}$ nebo pí̧ $\omega \mu \alpha$ u Empedoklea. ${ }^{\mathrm{v}} \mathrm{V}$ každém př́ípadě termín mohl nést některý původní smysl. ${ }^{\mathrm{vi}}$

Ačkoli není jasné, co slovo yóvırov, „co rodi““, „co plodi““, „,co je plné života“, znamená, lze vysledovat jeho biologické konotace nebo zobecnění původního konkrétního biologického významu. Současně tak i samotné

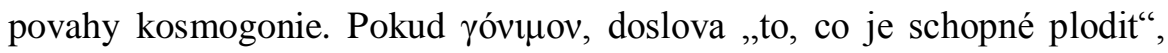
vyložíme ve významech „semeno“ či ,zárodek“, dostáváme se na pole embryologických či botanických pojmů. Jakoby se na počátku vzniku celého světa z $\tau$ ò ă $\pi \varepsilon$ po

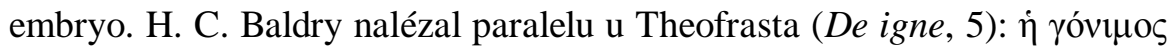

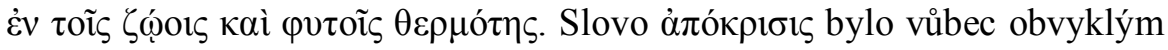
slovem pro oddělení semene od rodiče. 'Алокрıө̃̃vaı u Pseudo-Plútarcha bychom pak mohli vyložit v biologicko-embryologickém smyslu jako

${ }^{\mathrm{i}}$ Srv. Hölscher 1970, s. 292.

${ }^{\text {ii }}$ Marcus Aurelius, Ad se ips. IX,1,5.

iii Eirénaios, $A d v$. haer. II, 18,2 nebo II, 14.

${ }^{\text {iv }} D K 59 \mathrm{~B} 4$.

${ }^{v} D K 31 \mathrm{~B} 6$.

${ }^{\text {vi }}$ Srv. Kahn 1960, s. 57; KRS 2004, s. 170. 
„vyloučeni'“ a nikoli jako mechanické oddělení. Aristotelés uvádí spojení

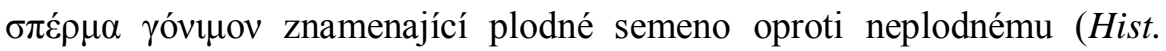
animal. 523a25) a Theofrastos (De igne 44) slovem yóvıov, jak jsme viděli, charakterizuje teplo Slunce, které je příčinou života zviŕrat a rostlin. I některá z dalších slov v pokračování Pseudo-Plútarchovy zprávy mohou mít biologické konotace. Tak $\varphi \lambda$ otós, překládané jako „kůra“, je odvozené od $\varphi \lambda \varepsilon ́ \omega$ a jako takové mohlo být ve velmi těsném vztahu ke generativnímu významu a v daném kontextu znamenat blánu, která se vytváří kolem vznikajícího organismu, at' již jde o živočicha nebo rostlinu. Mohlo tedy znamenat i plodovou blánu. Tak jej užívá Aristotelés pro membránu obklopující vejce. ${ }^{\mathrm{i}}$ Pro nás jej zachovává v daleko aktuálnějším anaximandrovském kontextu Áetios, ${ }^{\text {ii }}$ když jím popisuje ostnatou kůru prvních živočichů. Oba termíny se tedy objeví u Anaximandra hned dvakrát. H. C. Baldry vyslovil domněnku, že se Anaximandros pokusil porovnat „kůru“ světa s membránou tvořící se kolem vajec, embryí

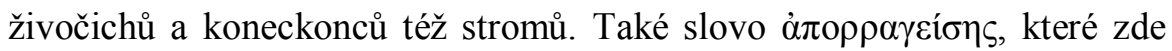
znamená „odlámání“ planoucí sféry, by mělo lepší význam v souvislosti s oddělením nového plodu $\mathrm{z}$ těla rodiče. ${ }^{\text {iii }}$

Zároveň si ovšem musíme být vědomi, že jakékoli př́ípadné biologické významy daného slova jsou neprůkazné a mohou být zavádějící. Zvláště pokud nahlédneme do Plútarcha, kde termín nenese biologické implikace. Návrhy, které vysvětlovaly rané stádium vzniku světa právě s odkazem k prostředkům pohlavního plození (F. M. Cornford ${ }^{\text {iv }}$ ), jdou za naši textovou evidenci.

\footnotetext{
${ }^{\mathrm{i}}$ Aristotelés, Hist. animal. 558a28.

ii Áetios, Plac. V, 19,4 = DK 12 A 30.

iii Srv. Baldry 1932, s. 29-30; Kahn 1960, s. 86-87; Naddaf 2005, s. 72-73.

${ }^{\text {iv }}$ Srv. Cornford 1932, s. 18.
} 


\section{Věčný pohyb a protiklady}

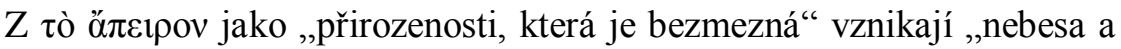
v nich světy (uspořádání)“. Pokud vznik, o němž píše Simplikios v podobě „oddělování protikladů věčným pohybem“, vyložíme v širším smyslu, jedná se obecně o způsob, jakým vzniká samotný svět.

Jakkoli není o věčném pohybu u Pseudo-Plútarcha doslovná zmínka, byt' se může skrývat právě za výrazem ,co trvá“, doxografie se shoduje, že oddělování protikladů se mělo odehrávat v rámci „,věčného pohybu“, který je tak př́ičinou nebo průvodním znakem vzniku nebes. ${ }^{i}$ Jaká je podstata věčného pohybu a jedná se o pohyb samotného apeira? O jeho povaze nemáme žádné bližší zprávy. Je ukázána pouze na pozadí vytváření univerza, kdy se v první fázi oddělily protiklady tepla a chladu.

Anaximandrův princip byl peripatetiky vymezen jako jeden, pohyblivý

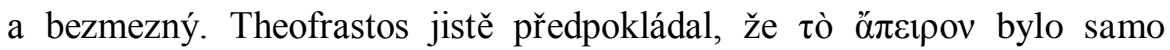
nadáno pohybem, jak lze očekávat z četných Aristotelových kritik předchůdců, kteří neuvedli jinou příčinu změny. Z peripatetického konceptu může pramenit i uváděná věčnost. Viděli jsme, že Aristotelés jmenuje Anaximandra mezi těmi, „kdo vedle bezmezna nepředpokládají

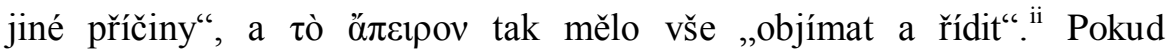

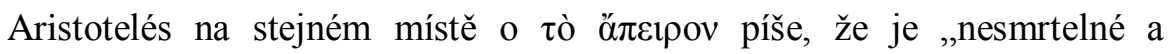
nehynoucí", lze jistou analogii spatřovat v jiné pasáži z Fyziky, kde se zmiňuje o „neustávajícím a nesmrtelném“ pohybu obsaženém ve věcech jako, ,jakýsi život"“:

${ }^{\mathrm{i}}$ Simplikios, In Arist. Phys. 24,13 = DK 12 A 9; 41,17-19; 150,22-25; Hippolytos, Ref. I,6,2 = DK 12 A 11.

ii Aristotelés, Phys. $203 \mathrm{~b} 6=D K 12$ A 15. 
„Je však otázka, zda pohyb, který dř́ve nebyl, někdy vznikl a zda opět zaniká tak, že se nic nepohybuje, či zda ani nevznikl, ani nezaniká, nýbrž vždy byl a vždy bude, a zda toto neustávající a nesmrtelné jest skutečně ve věcech jako jakýsi život, který jest ve všem, co je od přírody sestaveno a trvá. Všichni tudíž, kdo pojednávají nějak o př́rodě, tvrdí, že pohyb existuje, protože se zabývají otázkami o vzniku světa a zkoumání jich všech se týká vzniku a zániku, který by nemohl být, kdyby nebylo pohybu. Ale všichni, kteří prohlašují, že jest neomezený počet světu a že jedny vznikají a druhé zanikají, tvrdí, že pohyb existuje vždy - nebot' opakovaný vznik a zánik nutně jest spolu s jejich pohybem. Ti pak, kteří uznávají jeden svět, který < bud' trvá nebo> netrvá věčně, tvoří i o pohybu přiměřené předpoklady. “i

Jakoby úvodní slova evokovala mílétský způsob vnímání pohybu, možná zachycený u Thaléta v popisu duše jako schopnosti pohybu. ${ }^{\text {ii }}$ Ve své druhé části se ovšem pasáž zmiňuje nejspiše o pohybu u atomistů. Pokud byly Anaximandrovi - snad anachronicky - nekonečné světy připisovány, je možné, že Theofrastos měl v souvislosti s Mílétanem na mysli nějaký konkrétní pohyb - možná právě mechanický, jak se domnívá G. S. Kirk. Celý obraz by podporoval i Simplikios, který píše, že „následovníci Anaximandra, Leukippa, Démokrita a později Epikúra“ předpokládali „věčný pohyb“, „nebot' bez pohybu není vznik nebo zánik.“،iii Nejednalo se proto $\mathrm{v}$ príípadě oddělení protikladů o důsledek víru, jak se někdy předpokládá? G. Vlastos ${ }^{\mathrm{iv}} \mathrm{v}$ daném smyslu poukázal na možný význam

\footnotetext{
${ }^{\mathrm{i}}$ Aristotelés, Phys. 250b11-23. Překl. A. Kříž.

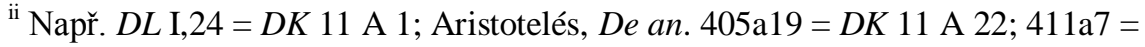
DK 11 A 22.

iii Simplikios, In Arist. Phys. 1121,5 = DK 12 A 17.

${ }^{\text {iv }}$ Srv. Vlastos 1947, s. 171.
} 


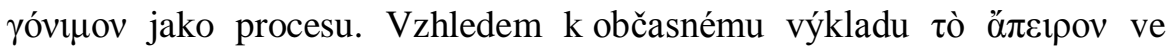

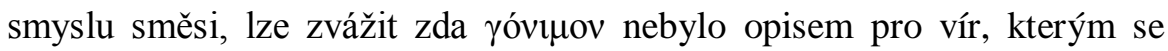
protiklady „oddělily“. Podporou by mohla být i analogie s Anaxagorou a kruhovým pohybem za jeho kosmogonie. Tomu by mohl napovídat Aristotelův text ze spisu $O$ nebi, kde je umístění Země ve středu univerza vysvětleno na pozadí působení víru. ${ }^{\mathrm{i}}$ Sám však následně Anaximandra odlišuje od většiny prrírodních myslitelů a právě uvedené koncepce, nebot' podle Mílét'ana měla Země setrvávat $\mathrm{v}$ klidu ve středu vzhledem k rovnováze. ii Dostupná doxografie navíc spojuje s vírem poprvé až

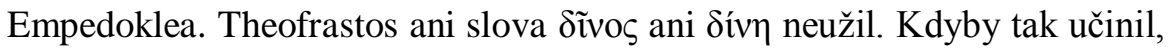
ještě více by akcentoval podobnost mezi Anaximandrem a Anaxagorou, na kterou sám upozorňoval. ${ }^{\text {iii }}$

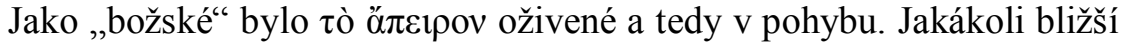
explikace povahy pohybu jde ovšem opět za naši textovou evidenci. Ačkoli Theofrastos Anaximandrovi připsal věčný pohyb jako prŕčinu vzniku nebes, žádný z textů povahu pohybu nepřibližuje a omezuje se pouze na jeho vymezení jako příčiny nebo rámce vzniku. Můžeme jen odhadovat, jak konkrétně došlo k oddělení protikladů, ke změně výchozích podmínek i samotnému kosmogonickému procesu. Sám Anaximandros však nejspíše otázku pohybu blíže neřešil, pokud si ji vůbec položil, nebot' $\tau$ ò ơ $\pi \varepsilon 1 \rho o v$ bylo božské a jako takové „vše obklopovalo a řídilo“. Bližší určení nemuselo být pro Mílét’ana vhodné již z povahy věci. Mohl pojednávat o „bezmezné přirozenosti“ jako o „moci př́rody“, z níž vše povstává. A zatímco psal o vzniku, zániku a vzájemném střídání všeho, kdy je pohyb míněn implicitně, peripatetici, pro něž byl pohyb pochopitelně klíčovou kategorií, pak v rámci své koncepce celý obraz pozměnili. Věčný pohyb by

\footnotetext{
${ }^{\mathrm{i}}$ Aristotelés, De caelo, 295a7-14.

ii Aristotelés, De caelo, 295b10 = DK 12 A 26.

iii Srv. KRS 2004, s. 165, 170-171; Naddaf 2005, s. 71.
} 
tak mohl být peripatetickou transpozicí za původní bezmezný vznik a zánik. i

V rámci věčného pohybu či životodárné síly apeira, moci $\varphi v ́ \sigma 1 \varsigma$, došlo k odloučení protikladů. Problému „odlučování“, „oddělování“,

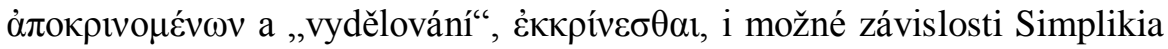
na Aristotelovi a jeho dvojici základních protikladů, jsme se věnovali na jiném místě. ii Aristotelés ve Fyzice řadí Anaximandra mezi ty, kteří „tvrdí,

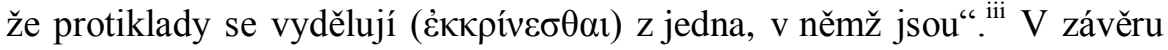

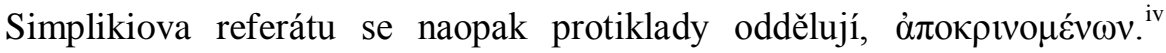
Pseudo-Plútarchos nechává na začátku své zprávy odlučovat nebesa

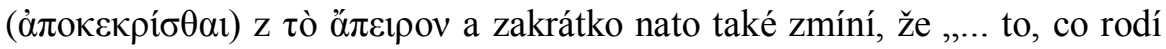

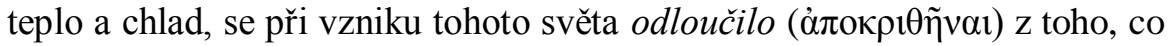
trvá, ..."Zdálo by se, že vznik „,všech nebes a uspořádání v nich“ by neměl být ani u Simplikia dán př́mo oddělením protikladů, ale tím, co je až následně zplodilo: yóvıov. Až z něho se následně vytvořila planoucí sféra

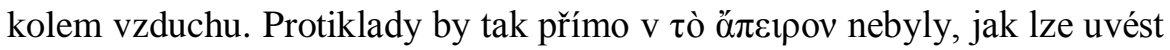

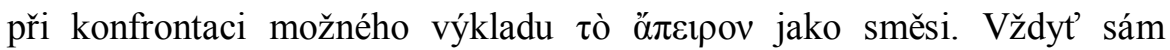
Theofrastos akcentuje podobnost mezi Mílét’anem a Anaxagorou za

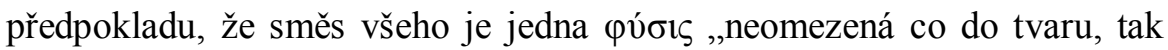

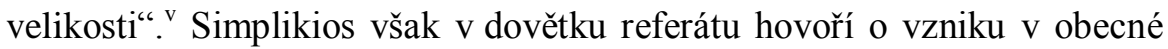
rovině. V rámci druhého překladu klíčové kosmogonické pasáže může být analogie ovšem zachována, nebot' zde se „to, co rodí odloučilo z protikladů tepla a chladu a následně samo vyrostlo v protiklady planoucí sféry a vzduchu.

\footnotetext{
${ }^{i}$ Srv. Kahn 1960, s. 42; KRS 2004, s. 164-165; Naddaf 2005, s. 71-72.

${ }^{i i}$ Viz Kočandrle 2008, s. 133-135.

iii Aristotelés, Phys. 187a20-21 = DK 12 A 9.

${ }^{\text {iv }}$ Simplikios, In Arist. Phys. 24,13 = DK 12 A 9.

${ }^{v}$ Simplikios, In Arist. Phys. 154,14 = DK 12 A 9a. Viz Simplikios, In Arist. Phys. $27,11-23=D K 59$ A 41 .
} 


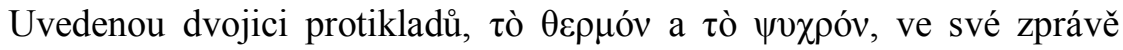
potvrzuje i Áetios. ${ }^{\text {i }}$ Svým způsobem se tak může jednat o podporu původu alespoň části textu u Theofrasta. Na významné úloze protikladů v Anaximandrově kosmogonii se doxografie shoduje. Zvláště na pozadí jejich role u Hérakleita ${ }^{\text {ii }}$ nebo Anaxagory. ${ }^{\text {iii }}$ A zatímco Simplikios vyjmenovává širší škálu protikladů v podobě „teplé, chladné; suché, vlhké; a ostatní،iv , Pseudo-Plútarchos uvádí pouze dvojici teplo a chlad. ${ }^{v}$ Áetios to potvrzuje, nebot' podobně podle něho je nebe ze směsi tepla a chladu. ${ }^{\mathrm{vi}}$ Nejedná se ovšem o kvality, ale spíše konkrétní věci či entity. Teplé tak nevyjadřuje přidanou vlastnost věci, která je teplá. Jde o samotnou konkrétní věc, protikladnou studené, které mohou být přitom za určitých podmínek sloučeny, podobně jako víno smíchané s vodou. O jejich skutečné podobě však můžeme pouze spekulovat. Navíc je pro archaickou dobu signifikantní, když ještě Simplikios do výčtu protikladů zahrne i „ostatní“. Jejich počet se ustálil až později v rámci nauky o prvcích, kdy je každý ze čtyř prvků vymezen na pozadí párových dvojic protikladů teplachladu a sucha-vlhka. ${ }^{\text {vii }}$

Proces odloučení v nejranější části kosmogonie má následnou paralelu ve vytvoření planoucí sféry kolem vzduchu, která vyroste z toho, „co rodí“. Zatímco první proces je popsán jako „odloučení“, druhý jako „růst“، a následné „odlámání“. V těchto fázích nalézá své vyjádření obraz o vzniku „všech nebes a uspořádání v nich“ $\mathrm{z}$,přirozenosti, která je bezmezná“. Setkáváme se navíc s konkrétními podobami protikladů. Místo kvalit tepla a chladu jsou uvedeny oheň a vzduch. Oba protiklady následně přímo vytvářejí nebeská tělesa. Jejich vzájemná vazba bude dále působit symetrii

\footnotetext{
${ }^{\mathrm{i}}$ Áetios, Plac. II, 11,5 = DK 12 A 17a.

ii $D K 22$ в 126.

iii $D K 59$ B 4; $D K 59$ B 8; $D K 59$ B 12; DK 59 B 15.

${ }^{\text {iv }}$ Simplikios, In Arist. Phys. $150,24=D K 12$ A 9.

${ }^{v}$ Pseudo-Plútarchos, Strom. $2=D K 12$ A 10.

${ }^{v i}$ Áetios, Plac. II,11,5 = DK 12 A 17a.

vii Srv. Kahn 1960, s. 40-42; Naddaf 2005, s. 71.
} 
celého světa vyjádřenou $v$ jeho cyklech a zaznamenanou i v Anaximandrově zlomku $D K 12$ B 1. Někde zde může mít svo̊j ozvuk Parmenidem zmiňovaná dvojice protikladů světla a tmy. ${ }^{i}$

\section{Zrození světa}

Nelze se ubránit dojmu, zejména v analogii s Áetiovou zprávou o Anaximandrově zoogonii, ${ }^{\text {ii }}$ že Anaximandros popisoval vznik světa právě v termínech organického života. Vždyt' svět je živý. Univerzum by pak povstávalo ze semene či zárodku podobně jako živý organismus. Tò ó $\pi \varepsilon$ ıov se stává doslova rodičem celého světa. G. Naddaf v této souvislosti připomíná hippokratovské texty shledávající podobnost mezi vývojem rostlin a embryí i mezi vývojem lidských embryí a univerzem. Ačkoli jsou různého stáří a oproti Anaximandrově době mladší, jejich stará vrstva uchovává některé prvky iónského myšlení. Mimo jiné z ní pocházejí texty, které edice Diels-Kranz zařadila mezi imitace „C“ Hérakleita z Efesu. ${ }^{\text {iii }}$

$\mathrm{Na}$ druhé straně, jak jsme výše uvedli, jakkoli mohly mít výklady lidského embrya a vzniku univerza podobného jmenovatele ve společném ochranném obalu, ṿ̛ív, nemusí být srovnání doslovné. Podle W. A.

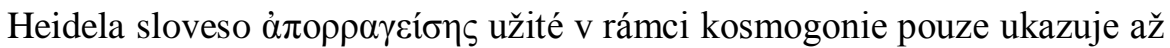
následné oddělení planoucí sféry, když se „odlámala“, zatímco pro popis rozlomení sféry bychom měli spíše očekávat sloveso $\pi \varepsilon \rho 1 \rho \rho \eta \gamma v v ́ v \alpha 1$. V př́ípadě živých tvorů se rozlamovala, doslova rozpraskala kolem $(\pi \varepsilon \rho 1 \rho \rho \eta \gamma \nu v \mu \varepsilon ́ v o v){ }^{\text {iv }}$

\footnotetext{
${ }^{\mathrm{i}}$ Srv. Hölscher 1970, s. 292-293.

ii Áetios, Plac. V, 19,4 = DK 12 A 30.

iii Srv. Kahn 1960, s. 86-87; Naddaf 2005, s. 72-73.

${ }^{\text {iv }}$ Srv. Heidel 1913, s. 688.
} 
Přesto jednotlivé popisy Anaximandrovy kosmogonie od oddělení semene či zárodku po vytvoření planoucí sféry a jejího odlámání mohou nést původní Mílét'anova přirovnání. Je otázkou, zda Anaximandros pouze neužil daná slova právě jako přirovnání, což je pro mílétské myšlení naprosto typické, nebo se opravdu jedná o adekvátní rovinu biologické argumentace. Kosmogonický proces by tak byl spontánní oproti mechanickému u Anaxagory či atomistů. Univerzum roste podobně jako živý organismus ze semene nebo zárodku. V prvním z uváděných překladů

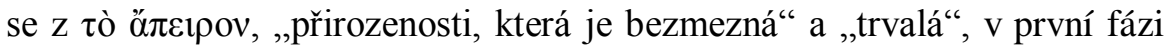
kosmogonického procesu odloučí semeno nebo zárodek schopný rodit klíčové síly pro vznik univerza - protiklady tepla a chladu. Doxografie se přitom shoduje, že vznik je dán oddělováním protikladů. Pochopíme-li

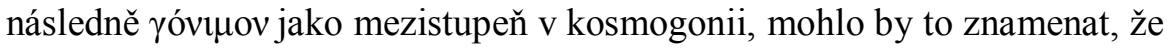
v sobě zmíněné protiklady obsahuje, či lépe je jimi „obtěžkané“, „těhotné“،

Гóvuov, které se na počátku kosmogonie stalo odlišné od $\tau$ ò ó $\pi \varepsilon \iota \rho o v$, je jakoby jeho částí. Jak si ale celý proces konkrétně představit co do prostoru? Otázka je fundamentální, nebot' vede $\mathrm{k}$ precizaci $\tau$ ò ö $\pi \varepsilon ı \rho o v$. Vzniká svět mimo něj nebo v něm? Dojde k odloučení yóvıนov, které se tak stane samostatné v jiné oblasti, nebo se právě až zde vše zakládá a až nyní je vůbec možné akcentovat jakékoli prostorové významy? Podle A. Finkelberga ${ }^{i i}$ se $\gamma o ́ v i \mu o v$ spíše odlišilo či vytvořilo $v$ rámci věčného, než že by se z něho jako takové oddělilo. Biologické analogie by se v takovém př́padě vztahovaly na vývoj embrya $\mathrm{v}$ těle matky. V př́padě druhého $\mathrm{z}$ překladů a předpokladu $\tau$ ò ój $\varepsilon$ ıрov ve smyslu bezmezné diference se vše děje v rámci spojení protikladů na tomto světě. A mezi tím, co trvá,

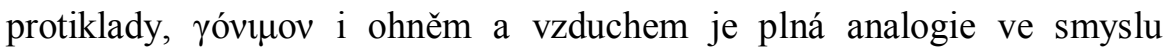
stupňované konkrétnosti. Гóvuov by nemuselo vyjadřovat kosmogonický

\footnotetext{
${ }^{\mathrm{i}}$ Srv. Hölscher 1970, s. 292; Kahn 1960, s. 86-87; Naddaf 2005, s. 72-73.

${ }^{\text {ii }}$ Srv. Finkelberg 1993, s. 245-246.
} 
mezistupeň, ale mohlo by být akcentem na zrod, který se právě začal odehrávat.

Ze semene nebo zárodku vyroste „kolem vzduchu, který je okolo země, jakási planoucí sféra, jako kůra kolem stromu“. Nevíme, zda se nejdříve vytvoří chladné jádro představované vzduchem kolem Země nebo naopak obal planoucí sféry. Můžeme spíše předpokládat, že se jedná o simultánní procesy. "Planoucí sféra“, $\varphi \lambda$ oyò $\sigma \varphi \alpha i ̃ \rho \alpha$, vede ke kulovité představě

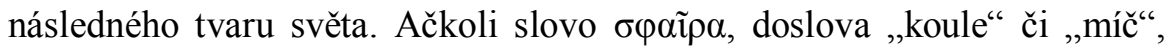
jasně naznačuje uvedený tvar, W. A. Heidel ${ }^{\mathrm{ii}}$ upozornil na nejednoznačnost ve významech „kulatosti“, „zaoblenosti“, „kruhovitosti“ spolu s nekritickým posuzováním starých kosmogonií optikou Eudoxových pojmů. Na daném místě by se nemělo jednat o sféru, nýbrž o kruh. Napovídat by tomu mohlo následné rozlomení planoucí sféry právě na prstence ohně nebeských těles, tedy $\mathrm{v}$ obdobný tvar. Na uvedenou představu tvaru Anaximandrova univerza může mít své vazby i analogie stromu, nebot' jak ukazuje R. Hahn, ${ }^{\text {iii }}$ sloupy prvních chrámů byly vyráběny ze dřeva nahrazeného v Iónii v 6. stol. př. Kr. kamenem. Horizontální průřez kmene i s letokruhy není nepodobný Zemi s koncentrickými kruhy nebeských těles Anaximandrovy kosmologie, kterým mohl sloužit za předlohu. Každý sloup je složený z mramorových bubnů. A právě bubnu sloupu bude $\mathrm{u}$ Anaximandra odpovídat samotný tvar Země - válec. Pokud jsou podobně nebeská tělesa tvořena prstenci ohně, mohlo by se jednat i o paralelu k původnímu tvaru planoucí sféry, která by ve skutečnosti nebyla sférou, ale válcem. Zvláště když se Pseudo-Plútarchos bezprostředně před popisem rané fáze kosmogonie zmíní o válcovité podobě Země. Přesto se domníváme, že přirovnání je nejspíše opravdu neseno pouze vykázáním těsné vazby planoucí sféry ke vzduchu. Sloveso $\pi \varepsilon \rho 1 \varphi v \tilde{\eta} v \alpha$ vedle spontánního růstu vyjadřuje právě těsnost této planoucí sféry ke vzduchu. Nelze vyslovit domněnku, že smysl připodobnění může spočívat i v přímé

\footnotetext{
${ }^{\text {i }}$ Srv. Bicknell 1966, s. 42.

ii Srv. Heidel 1913, s. 687-688.

iii Srv. Hahn 2001, s. 192-196, 216-217.
} 
vyživující funkci? Jako je kůra ze stromu ,živena“" (ve skutečnosti vyživuje strom lýko a kůra jej chrání), může se oheň živit z prvotní vlhkosti obsažené ve vzduchu. Nevíme, zda zmíněná sféra nemá následně souvislost s uvažovanou sférou stálic. Nebo zda spíše nemá navozovat tvar semene. Jisti si být v daném bodě nemůžeme. ${ }^{\mathrm{i}}$

Гóvinov se přemění v planoucí sféru okolo vzduchu, skutečných reprezentantů protikladů tepla a chladu. Zárodek-semeno tepla a chladu se projeví v konkrétních fenoménech. $\Phi \lambda$ ó $\xi$, „plamen“, „oheň“ na straně jedné a òń $\rho$, „vzduch“ na straně druhé. Slovem „,vzduch“ se zde však nejspíše myslí i „mlha“ či ,prvotní vlhkost“, podobně jako v jeho

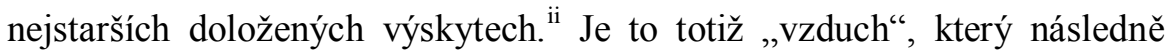
obklopí ohnivé prstence nebeských těles, přičemž oheň nebeského tělesa dále sálá pouze skrze průduch. Nejblíže má však k prvotní vlhkosti, která vyplňuje prostor uvnitř planoucí sféry. Právě jejím pozůstatkem má být následně moře. ${ }^{\text {iii }}$ Je zmíněna i Země nalézající se v obklopujícím vzduchu. Suchá země ovšem povstane až následně, kdy je původní vlhkost, z níž se „vynořri“", vysušována jako následek dalšího „odlučování“ sucha a vlhka. Přesto její zdánlivě mimochodné uvedení může vést $\mathrm{k}$ předpokladu, že Země nevznikla až postupně, ale byla již od samého počátku vzniku univerza. Jako jádro nebo pecka planoucí sféry se posléze „vynořila“ z obklopující vlhkosti.

Jak ale k vytvoření zmíněné planoucí sféry dojde, není jasné. Text přibližuje tři fáze vzniku světa - zatímco nejranější je popsána jako „odloučení", následná jako „růst kolem“, následována „odlámáním“. Při vědomí rozdílů mezi embryologickým a botanickým výkladem a současně jejich výše načrtnutých vzájemností, se lze ptát, zda je vytvoření sféry následkem dalšího odloučení $\mathrm{z}$,toho, co rodí“, jeho štěpením, nebo se

\footnotetext{
${ }^{\text {i }}$ Srv. Hölscher 1970, s. 292; KRS 2004, s. 171.

ii Srv. Kočandrle 2008, s. 210-224.

iii Áetios, Plac. III, 16,1 = DK 12 A 27; Alexandros z Afrodisiady, In Arist. Meteor. 67,3-11 = DK 12 A 27.
} 
jedná o proměnu, např́klad co do růstu a nabytí jiného tvaru, kdy by se dalo doslova hovořit o, „vyklíčení“ tepla a chladu. Nebo se jedná ještě o jinou změnu? Pokud prrijmeme embryologicko-botanický výklad za rámcově správný, mohli bychom celý obraz prostě vyložit jako následný růst a vývoj zárodku nebo semene v chladné (a vlhké) jádro obalené teplou (a suchou) slupkou planoucí sféry. ${ }^{\mathrm{i}}$

Další vývojovou fází ustavení světa je rozlámání (odlámání) planoucí

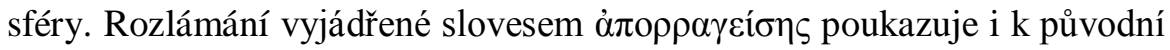
představě prostorového rozsahu planoucí sféry. Konkrétní důvody porušení sféry však neznáme, nebot' je dostupné texty nepřináší. Mohl by s nimi souviset i sklon ekliptiky, který měl Anaximandros objevit. Nevíme. Můžeme se proto pouze domnívat, že se jedná o důsledky vzájemného působení protikladných sil. Teplo (a sucho) planoucí sféry působí na vnitřní chlad (a vlhko). V celé soustavě bezesporu pokračují vzájemné interakce. Teplo planoucí sféry vysušuje vlhkost vzduchu-mlhy, která by zde měla být Pseudo-Plútarchem implicitně myšlena, přestože není přímo zmíněna. Zda se vprostřed vzduchu-mlhy následně zhušt'uje a usazuje Země jako to nejhustší jádro, taktéž nevíme. Pokud se Pseudo-Plútarchos jako jediný doslova vyjadřuje tak, že planoucí sféra měla vyrůst ,kolem vzduchu, který je okolo Země“, můžeme spíše předpokládat, že Země existovala již ve chvíli, kdy planoucí sféra vyrostla $\mathrm{z}$,toho, co rodí“. Vzduch-mlha se rozvolňuje-žred'uje, přičemž se jeho objem zvětšuje natolik, že již nemůže být dále držen obklopující sférou. Možná si lze představit třetí koncentrickou vrstvu mezi Zemí a planoucí sférou, která vzniká vypařováním z původní prvotní vlhkosti a vytváří čím dál větší tlak na sféru. Výpary vzduchu-mlhy již nemohou být dále drženy obklopující planoucí sférou a ta praskne. Podobnou představu nabízí Aristotelés v Meteorologice, ${ }^{\mathrm{ii}}$ kde popisuje vysušování oblasti nad původně vlhkou

\footnotetext{
${ }^{\text {i }}$ Srv. Hölscher 1970, s. 292; Kahn 1960, s. 87.

${ }^{\text {ii }}$ Aristotelés, Meteor. 355a21-25.
} 
Zemí působením tepla Slunce, způsobující vznik vzduchu a následné zvětšování celého nebe. Podobně podle Áetia ${ }^{i}$ síla vanutí (větru), které vyjde z hustého oblaku a rozdělí jej, působí blesk a hrom. ${ }^{\text {ii }}$

Jakmile se planoucí sféra odláme, uzavře se její oheň do kruhů

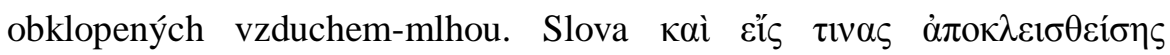

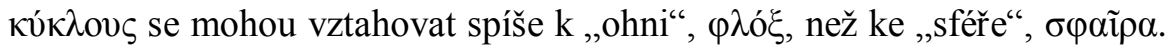
Rozlomením planoucí sféry na kruhy ohně dojde ke vzniku nebeských těles - Slunce, Měsíce a hvězd v podobě těchto ohnivých kruhů obklopených mlhou (o stálicích však nemáme žádné bližší zprávy). Můžeme předpokládat, že při odlámání planoucí sféry došlo k vychrlení vzduchumlhy původně uzavřeného uvnitř sféry a jeho expandování dále do prostoru. Vzdálenost, na kterou jsou vzduch a oheň vychrleny, by měla být minimálně rovna velikosti kruhu Slunce, který je největší. Sloveso

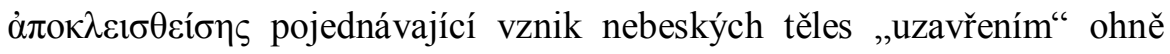
rozlámané planoucí sféry je opět ve vztahu k ,odloučeni““, $\alpha$, „obklopení“, $\pi \varepsilon \rho \imath \lambda \eta \varphi \theta \varepsilon \dot{v} \tau \alpha$, které pro popis vzniku nebeských těles užívá Hippolytos. iii Podle něho jsou nebeská tělesa také kruh ohně obklopeného

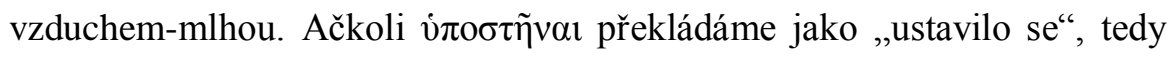
„Vzniklo“, může být jeho význam blízký i významům „přetrvalo“ nebo „zůstalo“ ve smyslu nebeských těles jako jediných pozůstatků někdejší planoucí sféry. ${ }^{\text {iv }}$

Z doxografie se dá usuzovat, že jakmile se odláme planoucí sféra a z jejích zbytků se vytvoří nebeská tělesa, teplo a světlo ohně dále sálá z průduchů v prstencích nebeských těles. " Působením zejména Slunce, které je výsostným zástupcem tepla, postupně vystoupí z masy chladného a

\footnotetext{
i Áetios, Plac. III,3,1 = DK 12 A 23.

${ }^{\text {ii }}$ Srv. Heidel 1913, s. 689; Kahn 1960, s. 87; Naddaf 2005, s. 73.

iii Hippolytos, Ref. I,6,4 = DK 12 A 11.

${ }^{\text {iv }}$ Srv. Heidel 1913, s. 689; Hölscher 1970, s. 293-294.

v Áetios, Plac. II, 16,5 = DK 12 A 18; II,20,1 = DK 12 A 21; II,21,1 = DK 12 A 21; II, 25,1 = DK 12 A 22; Hippolytos, Ref. I,6,4-5 = DK 12 A 11; Pseudo-Plútarchos, Strom. $2=D K 12$ A 10 .
} 
vlhkého prostředí Země. Další působení žáru Slunce vede k vysušování prvotní vlhkosti na Zemi a zanechání jejího zbytku - moře. Na Zemi tak oddělením protikladů vlhkého a suchého vlivem tepla Slunce vzniká moře a země. Důsledky vysušování následně umožní vznik nejen mořských tvorů, ale i suchozemských živočichů žijících na pevné zemi a mezi nimi člověka. Vše je určeno a vzchází ze vzájemnosti protikladů. Jakmile dojde v první fázi kosmogonického procesu k odloučení protikladů, jsou všechny následné př́rodní cykly určeny jejich oboustranným zasahováním. A pokud budeme akcentovat druhou verzi našeho překladu kosmogonického obrazu,

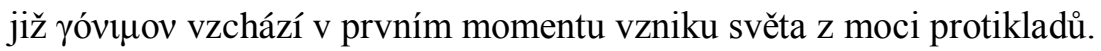

\section{Závěr}

Ačkoli jsme v rámci kosmogonie akcentovali zejména biologické konotace, nelze prohlásit, že model biologického rození je naprosto adekvátní. Již z toho důvodu, že je založen na velmi problematickém místě a termínech. Pokud nejsme schopni dostatečně rozhodnout již o významu

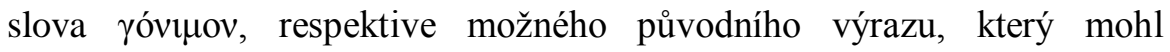
Anaximandros užít, může být jakákoli interpretace stavějící na biologických aspektech zavádějící. Jak poznamenal G. S. Kirk, ${ }^{i}$ v uvedené Pseudo-Plútarchově pasáži se jedná převážně o obecné termíny a jejich užití v embryologii mohlo být právě tak náležité jako v kosmogonii.

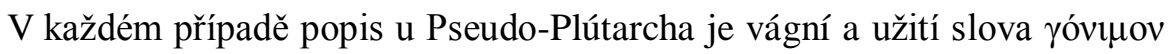
může napovídat o jeho vlastních pochybách. Je možné, že celý výklad je výsledkem různých nepochopení nebo důsledkem recepce původního Mílét'anova textu, který na daném místě prostě nebyl přesný. Vzhledem k uvažovanému charakteru spisu lze předpokládat, že kosmogonie v něm ani nebyla lépe popsána.

${ }^{\mathrm{i}}$ Srv. KRS 2004, s. 170-171. 
O prvním stádiu světa tedy máme velmi kusé informace, které do celé problematiky mnoho světla nevnáší. Dostatečná a uspokojivá rekonstrukce raných fází Anaximandrovy kosmogonie je vzhledem k nedostatku textových pramenů nemožná. Tápeme, odhadujeme původní slova a někdejší významy překryté pozdními termíny a interpretacemi. Máme k dispozici krátký text, který obsahuje jak přirovnání, která Mílét’ané zjevně při výkladech užívali, tak možná autentická slova jako „kưra“,

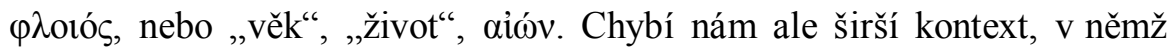

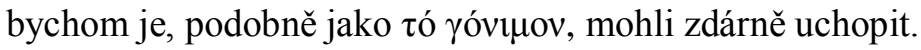

Seznam zkratek citovaných děl

DK - Diels, H., Kranz, W., Die Fragmente der Vorsokratiker, Griechisch und Deutsch, Zürich 2004/2005.

Dox. - Diels, H., Doxographi Graeci, Berlin 1879.

KRS - Kirk, G. S., Raven, J. E., Schofield, M., Předsókratovští filosofové. Kritické dějiny s vybranými texty, překl. F. Karfík, P. Kolev, T. Vítek, Praha 2004.

LSJ - Liddell, H. G., Scott, R., A Greek-English Lexicon, With a Revised Supplement: Jones, H. S., McKenzie, R., Oxford 1996. 
Áetios

Plac. - Placita philosophorum

Alexandros z Afrodisiady

In Arist. Meteor. - In Aristotelis Meteorologica commentaria

Aristofanés

Ran. - Ranae

Aristotelés

De an. - De anima

Hist. animal. - Historia animalium

Meteor. - Meteorologica

Phys. - Physica

Aurelius, Marcus A. Antonius

Ad se ips. - Ad se ipsum 
Diogenés Laertios

DL - Diogenis Laertii Vitae philosophorum

Eirénaios

Adv. haer. - Adversus haereses

Euripidés

El. - Electra

Eusebios

Praep. evan. - Praeparatio evangelica

Hermiás

Irr. gent. phil. - Irrisio gentillium philosophorum

Hippolytos

Ref. - Refutatio omnium haeresium 
Porfyrios

De abst. - De abstinentia

Pseudo-Plútarchos

Strom. - Stromata

Simplikios

In Arist. Phys. - In Aristotelis Physicorum libros commentaria

Themistios

Or. - Orationes

\section{Seznam použité literatury}

Prameny

Diels, H., Kranz, W., 2004/2005, Die Fragmente der Vorsokratiker, Griechisch und Deutsch, Zürich.

Diels, H., 1879, Doxographi Graeci, Berlin.

Hippolytus, 1986, Refutatio omnium haeresium, M. Marcovich (ed.), Berlin-New York. 
Liddell, H. G., Scott, R., 1996, A Greek-English Lexicon, With a Revised Supplement: Jones, H. S., McKenzie, R., Oxford.

České překlady pramenů

Aristotelés, 1996, Fyzika, překl. A. Kř́iž, Praha.

\section{Sekundární literatura}

Baldry, H. C., 1932, „Embryological Analogies in Presocratic Cosmogony“", in: Classical Quarterly, 26, s. 27-34.

Bicknell, P. J., 1966, „TO AПEIPON, AПEIPO $\Sigma$ AHP and TO ПEPIEXON“, in: Acta Classica 9, s. 27-48.

Burnet, J., 1930, Early Greek Philosophy, London.

Cornford, F. M., 1932, Before and after Socrates, Cambridge.

Finkelberg, A., 1993, „Anaximander's Conception of the Apeiron“, in: Phronesis, 38, s. 229-256.

Hahn, R., 2001, Anaximander and the Architects, New York.

Heidel, W. A., 1912, „On Anaximander“, in: Classical Philology 7, s. 212234. 
Heidel, W. A., 1913, „On Certain Fragments of the Pre-Socratics: Critical Notes and Elucidations“, in: Proccedings of the American Academy of Art and Sciences 48, s. 681-734.

Hölscher, U., 1970, „Anaximander and the Beginnings of Greek Philosophy“, in: Furley, D. J., Allen, R. E. (ed.), Studies in Presocratic Philosophy, New York, s. 281-322.

Kahn, Ch. H., 1960, Anaximander and the Origins of Greek Cosmology, New York.

Kirk, G. S., Raven, J. E., Schofield, M., 2004, Předsókratovští filosofové. Kritické dějiny s vybranými texty, překl. F. Karfík, P. Kolev, T. Vítek, Praha.

Kočandrle, R., 2008, Fysis iónských myslitelů, Rozprava nad peripatetickou dezinterpretací. Červený Kostelec.

Kratochvíl, Z., 2010, Iónie mezi mořem a nebem, Odkaz archaické vnímavosti, $\mathrm{v}$ tisku.

Naddaf, G., 2005, The Greek Concept of Nature, New York.

Vlastos, G., 1947, „Equality and Justice in Early Greek Cosmologies“, in: Classical Philology 42, s. 156-178. 